\title{
THREATENED FISHES OF THE WORLD: Cottus hispaniolensis Bacescu-Mes- ter, 1964 (Cottidae)
}

\author{
Carla Sousa-Santos ${ }^{1 *}$, Joana Isabel Robalo ${ }^{1}$, Ana Pereira ${ }^{1}$, Ignacio Doadrio² \\ ${ }^{1}$ Eco-Ethology Research Unit, ISPA Universitary Institute, Rua Jardim do Tabaco 34, 1149-041 Lisbon, Portugal \\ ${ }^{2}$ Museo Nacional de Ciencias Naturales, CSIC, José Gutiérrez Abascal 2, 28006 Madrid, Spain \\ * Corresponding author, E-mail: carla.santos@ispa.pt
}

\begin{tabular}{|c|c|}
\hline ARTICLE INFO & ABSTRACT \\
\hline $\begin{array}{l}\text { Received: } 12 \text { March } 2014 \\
\text { Received in revised form: } 5 \text { May } 2014\end{array}$ & $\begin{array}{l}\text { Cottus hispaniolensis is a critically endangered cottid fish which is endemic } \\
\text { from the Pyrenanean Garonne river basin. }\end{array}$ \\
\hline
\end{tabular}

Accepted: 5 May 2014

Available online: 7 May 2014

\section{Keywords:}

Cottus hispaniolensis

Endemic species

Conservation

\section{COMMON NAME}

Cavilat (Spanish), Chabot des Pyrénées (French) - Figure 1.

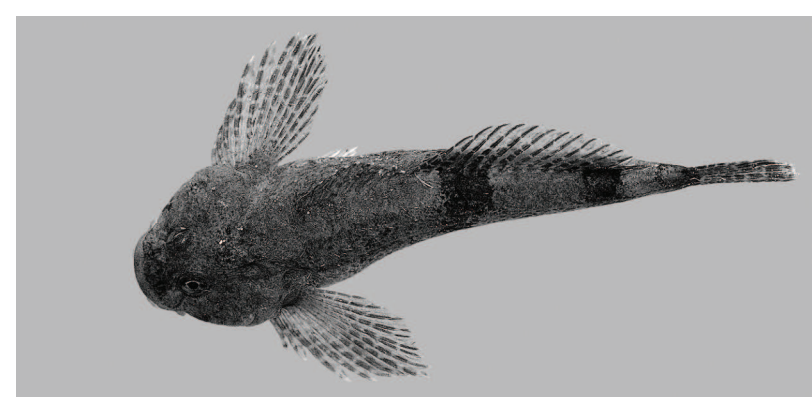

Fig 1. Cottus hispaniolensis (Photo credit: Ignacio Doadrio)

\section{CONSERVATION STATUS}

Critically Endangered according to the IUCN guidelines (Doadrio et al., 2011) and Least Concern according to Freyhof and Kottelat (2008) due to lack of data.

\section{IDENTIFICATION}

This small cottid (up to $100-150 \mathrm{~mm} \mathrm{TL}$ ) presents a stout caudal peduncle (length $14-19 \%$ SL, depth 7-9\% SL and 1.52.4 times in its length); prickling in adults; eye diameter 19$22 \% \mathrm{HL}$; interorbital distance 0.9-1.3 times in eye diameter; last anal-fin ray with membrane connecting to body along 0.5 of its length; last dorsal-fin ray connected to body by a membrane along 0.5-1.0 of its length; membrane between pelvic fin and body on about $1 / 5$ of last ray; membranes between pelvic-fin rays broad but narrower distally; and lateral line complete 33-35+1 pores (Freyhof et al., 2005; Keith et al., 2011). It differs from all other European Cottus species (except Cottus poecilopus) by having conspicuously tessellated pelvic-fin rays, and from C. poecilopus by possessing a single chin pore (Freyhof et al., 2005).

\section{DISTRIBUTION}

This species is endemic to the Garonne river basin, located in the central part of the Pyrenean mountain range.

\section{ABUNDANCE}

It has an estimated area of occupancy of less than 2,000 $\mathrm{km}^{2}$ and an extent of occurrence of less than $20,000 \mathrm{~km}^{2}$ (Freyhof and Kottelat, 2008). An accentuated decline trend was observed in its distribution area in the last few years, as 
few to no individuals were captured throughout most of the Garonne River and its tributaries (Doadrio et al., 2011).

\section{HABITAT AND ECOLOGY}

C. hispaniolensis typically occurs in the headwaters of streams with stone substrate and clear, cool and moderate to swift waters (Doadrio et al., 2011). It feeds mostly on insects and benthic crustaceans and has nocturnal habits (Doadrio et al., 2011).

\section{REPRODUCTION}

The reproduction occurs between March and June and females guard their eggs (Doadrio et al., 2011). The maturation age is attained at $4 \mathrm{~cm}$ in total length (Doadrio et al., 2011).

\section{THREATS}

Low water availability resulting from damming and captures for agriculture, urban pollution and unnatural flow regimes resulting from flow regulations which meet electrical power demands (Doadrio et al., 2011; Keith et al., 2011).

\section{CONSERVATION}

Active conservation measures are needed since population densities are very low and often no individuals were sampled along most of its distribution area (Doadrio et al., 2011). Population genetic studies are still lacking.

\section{CONSERVATION RECOMMENDATIONS}

Implementation of water management that mimics the natural hydrographic regime, establishment of minimum and ecological flows, and ex-situ conservation programs.

\section{ACKNOWLEDGMENTS}

This study was funded by project CGL2010-15231-BOS (MNCN-CSIC) and by FCT - Portuguese Foundation for Science and Technology (partially FEDER funded), under the multiannual financing programme UI\&D 331/94 and the project PTDC/AAC-CLI/103110/2008. C. Sousa-Santos was supported by a Post-doctoral grant from FCT (SFRH/ BPD/29774/2006).

\section{Sažetak}

\section{UGROŽENE VRSTE RIBA U SVIJETU: Cottus hispaniolensis Bacescu-Mester, 1964 (Cottidae)}

Cottus hispaniolensis je kritično ugrožena vrsta ribe iz porodice Cottidae, a endemska je u slivu pirenejske rijeke Garonne.

Ključne riječi: Cottus hispaniolensis, endemska vrsta, zaštita

\section{REFERENCES}

Doadrio, I., Perea, S., Garzón-Heydt, P., González, J. L. (2011): Ictiofauna continental española - bases para su seguimiento. Gobierno de España, Ministerio de Medio Ambiente y Meio Rural y Marino, Madrid. 610 p.

Freyhof, J., Kottelat, M. (2008): IUCN Red List of Threatened Species: Cottus hispaniolensis. [Cited in 2014 February 17]. Available from: http://www.iucnredlist.org

Freyhof, J., Kottelat, M., Nolte, A. (2005): Taxonomic diversity of European Cottus with description of eight new species (Teleostei: Cottidae). Ichthyological Exploration of Freshwaters, 16, 2, 107-172.

Keith, P., Persat, H., Feunteun, É., Allardi, J. (2011): Les poissons d'eau douce de France. Biotope, Mčze; Muséum national d'histoire naturelle, Paris. $552 \mathrm{p}$. 